\title{
Management Maintenance Tangible and Intangible Cultural Heritage through Public Private Partnership for The Purpose of Sustainable Tourism Destination
}

\author{
Heldi \\ Visual Art and Design \\ Faculty of Languages and Arts \\ heldiensten@yahoo.co.id
}

\begin{abstract}
The paper and study aims to explore the determinants of the success of PPP in the Management and Maintenance of tangible and intangible cultural heritage, and to identify what are the parameters of the main factors of sustainable tourism destinations. The discussion is addressed to stakeholders, institutions, academics and decision makers who directly involved both private and community governments in Indonesia, especially West Sumatra. This concept shows there are 5 determinants of the success of PPP in the management and maintenance of tangible and intangible cultural heritage. Tangible and intangible cultural heritage as a product of culture and folk art have a relationship with internal factors and external factors in the performance of PPP success. While the factors used as the parameters of sustainable tourism destinations are, economic factors, social factors, cultural and environmental factors. This relationship awakened a model of PPP success factors in the management and maintenance of tangible and intangible cultural heritage for the purpose of sustainable tourism destinations in Indonesia.
\end{abstract}

Keywords-PPP, Cultural Heritage, Tangible, Intangible, Destination, Sustainable Tourism

\section{INTRODUCTION}

Indonesia National Development is a continuous series covering all aspects of life of the nation and state, among them development in the field of culture. The national development in the cultural field of $2005-2009$ has been heading in the right direction with many advances, although still found some problems (Dadang, 2010). Based on the implementation of the achievement of the 1st RPJMN sustainability objective for the period of 2004-2009, the second RPJMN for the 2010-2014 period emphasizes more on the consolidation of positive, productive and creative new values in order to strengthen the assets values of cultural facilities and character nation. According to Davidson, (1991) cultural heritage is defined as the product or asset of tangible and intangible cultural products of the values of past civilization traditions that are the basic constituents of a group or nation. The understanding of cultural heritage is similar to the cultural sense according to Young (Kroeber, and Kluckhohn, C, 1952). But it can also be interpreted as a past cultural heritage treasure used for the life of the community now and then inherited for future generations on an ongoing basis.

Cultural heritage, according to Davidson (1991: 2) as 'the product or result of the physical culture of different traditions and achievements in the form of values of the past that are central elements in the identity of a group or nation'. So the cultural heritage is the result of physical culture (tangible) and cultural values (intangible) of the past. Cultural values of the past (intangible heritage) and tangible is derived from local cultures in the archipelago, including: traditions, folklore and legends, mother tongue, oral history, creativity (dance, song, drama performances), the ability adapt and uniqueness of the local community (Galla, 2001: 12).

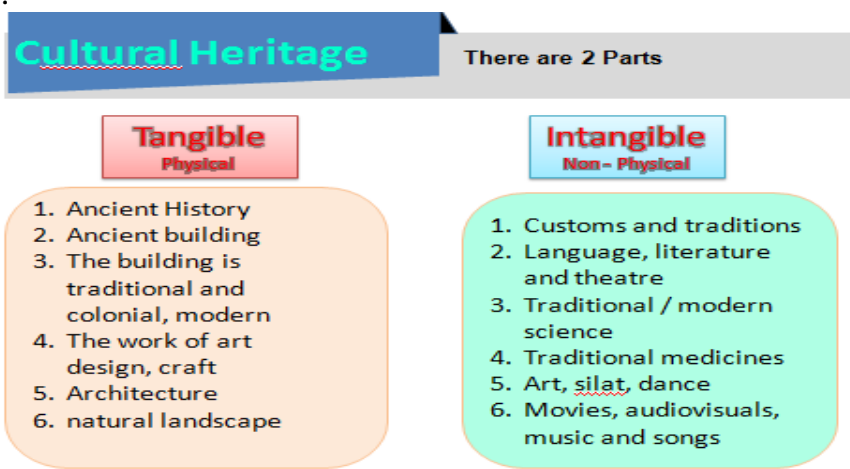

Fig. 1. The Cultural heritage Tangible and Intangible 
Development of tangible and intangible cultural heritage can be maintained and utilized for the purpose of development of tourism destinations in a sustainable manner. Tangible heritage is often classified as immovable heritage and movable heritage. Unmoved cultural heritage is usually in the open and consists of: sites, historic sites, land and water landscapes, ancient and / or historic buildings, hero statues (Galla, 2001: 8). The cultural heritage of moving is usually indoors and consists of: cultural heritage objects, artwork, archives, documents, and photographs, printed papers, audiovisual tapes, videos and films (Galla, 2001: 10).
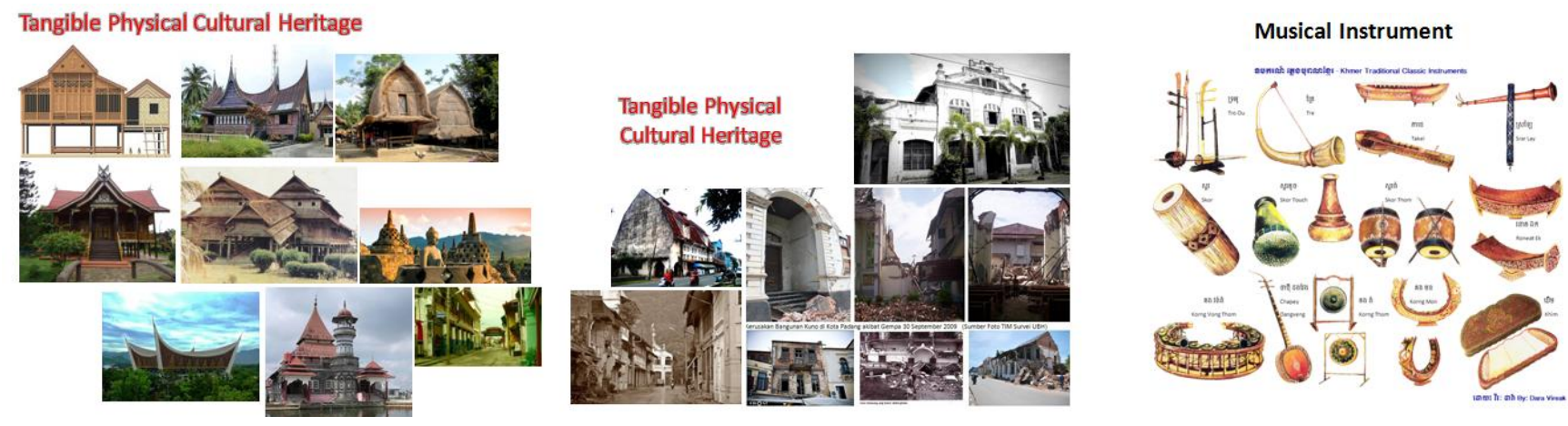

Intangible Non-Physical Cultural Heritage

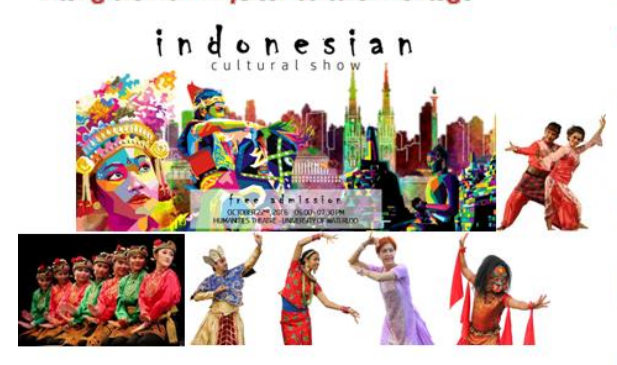

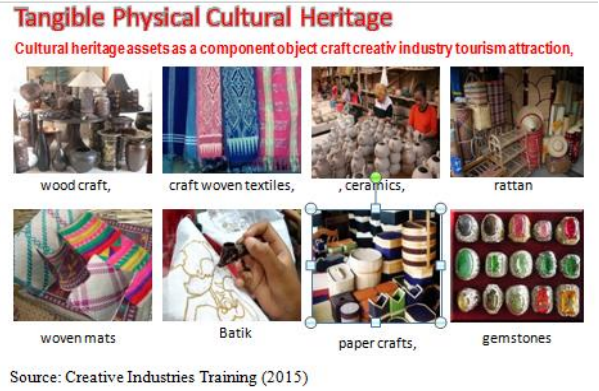

Intangible Non-Physical Cultural Heritage

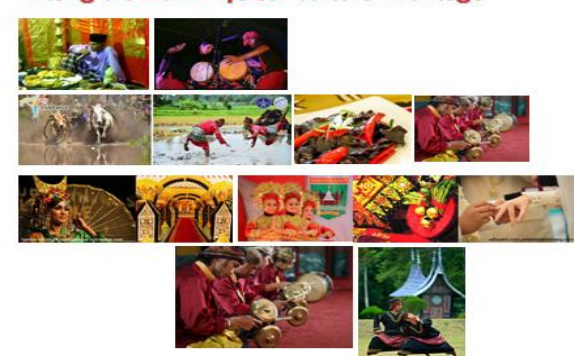

Fig. 2. Types of The Cultural heritage Tangible and Intangible

Lack of nation's ability to manage and maintain tangible and intangible cultural assets. In the era of regional autonomy, the management and maintenance of cultural heritage assets is the responsibility of local governments. But until now, the quality of management and maintenance in its implementation has not been optimal, very diverse. The variety of management quality is not only caused by the small amount of fiscal capacity, but also the lack of understanding, appreciation, awareness, and commitment of local government to the value of cultural richness. The management of cultural wealth also still not fully apply the principles of good management and maintenance (good governance). Meanwhile, the appreciation and love of the community for cultural heritage assets and domestic products is still low, which is partly due to the limited ability of the government in the management and maintenance of cultural heritage assets (Amaratunga et al 2000; Pitt and Hinks 2001).

In accordance with the direction and objectives of socio-cultural development, BAPPENAS (2012) establishes four main programs in the cultural sector, namely:

i. Program development of economic values, socio-cultural nation

ii. Program of maintaining cultural diversity

iii. Local arts and cultural development programs

iv. Heritage heritage asset management program.

\section{A. Concepts of Management and Maintenance}

The phenomenon of the management and maintenance of cultural heritage assets and facilities is a fundamental strategic issue in the life of modern society, the management of tangible and intangible assets and intangible cultural facilities is a complete activity and the process of its activities is less attractive in various talks for developing countries (Seeley 1976; Collis 1996; Wood 1999).

However, the changing time, management and leadership of the organization, for developed countries, cultural heritage assets, warm in meetings, talks and discussions, became one of the regional development goals, where the maintenance of cultural 
heritage is increasing as a tourism resource sustainable (Best et al 2003; Chotipanich 2004). Urgency of several issues related to the management and maintenance of cultural heritage assets in Indonesia:

a. Changes in the function of tangible and intangible cultural heritage assets

b. The occurrence of physical changes, neglect and even loss of cultural heritage assets,

c. The not yet optimal regulation of local regulations governing maintenance management to support the preservation of cultural heritage assets.

d. Not yet effective management system and maintenance of cultural heritage facility assets.

Optimization of cultural heritage assets

a. Work processes in asset management aimed at optimizing the physical potential, location, value, amount / volume, legality and economy of assets.

b. The assets controlled by LGs are identified and grouped into potential assets.

c. Potential assets can be grouped by leading sectors, which become the foundation of a national economic development strategy, both in the short, medium and long term

d. The criteria for determination should be measurable and transparent

e. Assets that can not be optimized must be searched for the cause. For example, what are legal, physical, low economic, or other factors?

f. The end result of this stage is recommendations in the form of targets, strategies and programs to optimize controlled assets

To solve the above problems, PPP is one of the most important schemes to fill the gap in the financial gap. The inclusion of funding from the private sector is very helpful to the Government in achieving sustainable infrastructure availability targets. Apart from the funding sector, the private sector also has the advantage of human resources and technological progress.

The success factor of the

\begin{tabular}{|l|l|}
\hline Maintenance Management Project \\
\hline COMPONENT & Sub- COMPONENT \\
\hline - Comfort & \begin{tabular}{l} 
Resource \\
- Effort \\
- Leadership \\
- The right technology \\
: experience \\
- Specialties available \\
- Manage \\
: Plan \\
- Build (operation) \\
- Harmony. \\
\hline - Information Systems \\
- Required status
\end{tabular} \\
\hline
\end{tabular}

Fig. 3. The success factor maintenance management project

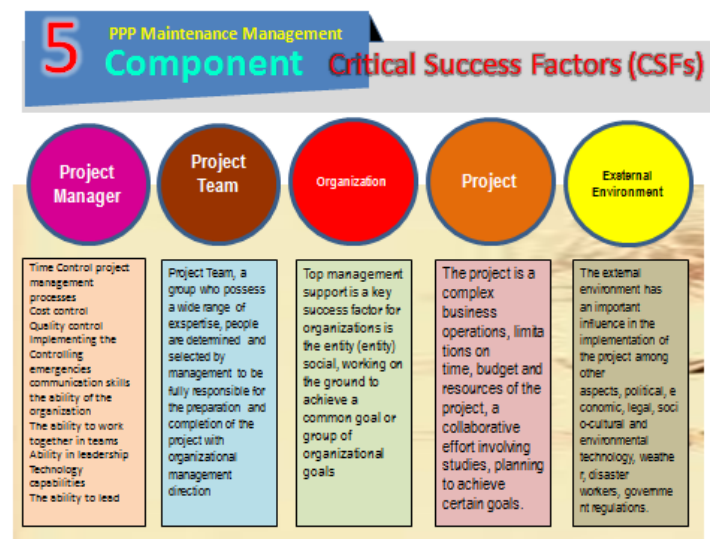

Fig. 4. 5 Component CSFs PPP maintenance management

\section{B. The concept of Public-Private Partnership (PPP)}

Public-Private Partnership (PPP) or Public Finance Initiative (PFI) approach has long been implemented in developed countries such as the UK, Germany, Australia and the United States, developing the pattern of PPP or PFI This is to help various development and operations. Developing countries the concept of PPP or PFI has already begun in dealing with some project development. In Indonesia, it is known as a partnership where the government gives authority to the public and / or private sector to implement some and / or all development and / or operation. In Indonesia, the pattern of PPP or PFI cooperation has been done by several state companies (SOEs) engaged in infrastructure such as PT Angkasa Pura, PT Pelindo, Batam Authority Body (PUSPAR, UGM 2001), PT Jasa Marga, PT PAM Jaya, PT Telkom or PT Indosat, and other companies. (Team KPS 2002). But in its application in the field of management and maintenance of cultural heritage assets the government has never done cooperation with foreign parties. This is because foreigners are less interested to invest their capital in this field because the profit is very small. 
The goal of the concept PPP

The concept of PPP is a complex system involving various stakeholders and institutions. Knowledge, resources, management, financing, regulation and risk.

The goal of PPP development is not only to address the very limited issue of government funding, but also to add value to the project of managing and maintaining the cultural heritage of government, private and public, through creativity and innovation of the private sector.

PPP Investment Process consists of 9 steps as described below

- Project Selection

- Public Consultation

- Feasibility Study

- Risk Review

- Form of Cooperation

- Government Support

- Procurement

- Implementation

- Monitoring

Source: private government cooperation (PPP), 2010

Table 1 Review of PPP implementation in infrastructure sector and its implementation.

\begin{tabular}{|c|c|c|}
\hline No. & Research & Sources \\
\hline 1. & $\begin{array}{c}\text { The private sector } \\
\text { partnerselection, public sector partner selection }\end{array}$ & $\begin{array}{c}\text { Zhang (2004, 2005b), Zhang (2006a, 2006b), } \\
\text { Queiroz (2007 }\end{array}$ \\
\hline 2. & Infrastructure project success factors selection & $\begin{array}{c}\text { Zhang (2005a), Algarni, Arditi, Polat (2007), } \\
\text { Touran. Lonez (2006) }\end{array}$ \\
\hline 3. & $\begin{array}{c}\text { Infrastructure projects studies, analysis, aintenance } \\
\text { solutions }\end{array}$ & $\begin{array}{c}\text { Mohamed, AbouRizk (2005), Karam Karim, } \\
\text { Karam Jad, Einstein }(2007 \text { a, 2007b), Khalafallah, El-Rayes (2006) }\end{array}$ \\
\hline 4. & $\begin{array}{l}\text { PPP projects in the countries of the world best } \\
\text { practices, PPP project risk factors study }\end{array}$ & $\begin{array}{l}\text { Li et. al. (2005), Abdel Aziz (2007), Chan Albert } \\
\text { et. al. (2010), Meidute, Paliulis (2011), Medda (2007), Satish, } \\
\text { Shah (2009), Jin (2010a, 2010b), Xu et. al. (2012) }\end{array}$ \\
\hline 5. & MRG ir TRC models & Ashuri, Kashani, Lu (2010), Jun (2010) \\
\hline 6. & $\begin{array}{c}\text { Sustainable } \\
\text { development approach }\end{array}$ & $\begin{array}{c}\text { Vaiškūnaitė, Miauriauskas, Špakauskas (2012), Bradulienè, } \\
\text { Vasarevičius (2012), White, Noble (2013), Salman, Skibniewski, } \\
\text { Bash (2007), Zhang (2005b), Griškevičiūte Gečienè, } \\
\text { Burinskienè (2012), Shina, Uzkalna (2013), Queiroz, Motta } \\
\text { (2012),Jakimavičius, Burinskienè (2013) }\end{array}$ \\
\hline
\end{tabular}

Types of PPP from several sources of literature

\begin{tabular}{|c|c|c|c|c|c|c|c|c|c|c|c|c|}
\hline $\begin{array}{l}\text { Bent } \\
1 . \\
2 . \\
3 . \\
4 . \\
5 . \\
6 . \\
7 . \\
8 . \\
9 . \\
10 . \\
11\end{array}$ & $\begin{array}{l}\text { ule Jenis-jenis Modelitas public priva te parnerships (PPP) } \\
\text { DB (design build) } \\
\text { DBO (design build operate) } \\
\text { DBFO (design build finance operate) } \\
\text { BOT (build-operate transfer). } \\
\text { BOOT (build-own operate transfer) } \\
\text { DBOM (design build operate maintenance) } \\
\text { ROO (buld-own operate) } \\
\text { ROT (rehabilitation operasional transfer) } \\
\text { BIT (build leasing transfer) } \\
\text { OMC (operate managemnt contract) } \\
\text { II (Joint Initiatives) }\end{array}$ & $\frac{5}{3}$ & 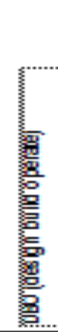 & 浸 & 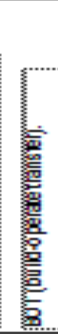 & 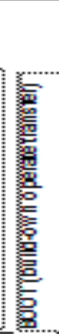 & 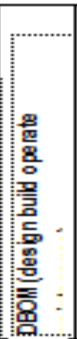 & 音, & 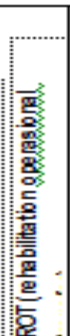 & : & 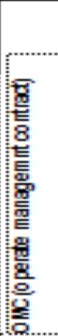 & 曑 \\
\hline & & 1 & 2 & 3 & 4 & 5 & 6 & 7 & 8 & 9 & 10 & 11 \\
\hline 1. & ADB (Asian Development Bank). & $\mathbf{x}$ & $\mathbf{x}$ & $\mathbf{x}$ & $\mathbf{x}$ & $\mathbf{x}$ & - & $\mathbf{m}$ & & $\mathbf{x}$ & $\mathbf{m}$ & $\mathbf{m}$ \\
\hline 2. & MGiller, J B. (2000). & - & - & $\mathbf{x}$ & $\mathbf{x}$ & $\mathbf{x}$ & $\mathbf{x}$ & $\mathbf{x}$ & $\mathbf{x}$ & $\mathbf{x}$ & - & - \\
\hline 3. & WBI (Word Bank Institute) & - & $\mathbf{x}$ & $\mathbf{x}$ & $\mathbf{x}$ & $\mathbf{x}$ & $\mathbf{x}$ & - & $\mathbf{x}$ & - & $\mathbf{x}$ & - \\
\hline 4. & Own elaboration based on Buljevich et al. 1999 & $\mathbf{m}$ & $\mathbf{x}$ & $\mathbf{m}$ & $\mathbf{x}$ & $\mathbf{m}$ & - & $\mathbf{m}$ & - & - & - & - \\
\hline 5. & Yescombe 2003 & $\mathbf{m}$ & $\mathbf{x}$ & $\mathbf{m}$ & $\mathbf{x}$ & $\mathbf{m}$ & - & $\mathbf{m}$ & - & - & - & - \\
\hline 6. & European Commission 2003 & $\mathbf{x}$ & $\mathbf{x}$ & $\mathbf{x}$ & $\mathbf{x}$ & $\mathbf{x}$ & - & $\mathbf{x}$ & - & - & - & - \\
\hline 7. & The National Conference of State Legislatures. (2010) & $\mathbf{m}$ & $\mathbf{x}$ & $\mathbf{m}$ & $\mathbf{x}$ & $\mathbf{m}$ & $\mathbf{x}$ & $\mathbf{m}$ & - & $\mathbf{m}$ & $\mathbf{m}$ & - \\
\hline 8. & Department of the Environment, Heritage and Local Government(2002) & $\mathbf{x}$ & $\mathbf{x}$ & $\mathbf{x}$ & - & - & - & - & $\mathbf{x}$ & - & $\mathbf{m}$ & $\mathbf{x}$ \\
\hline 9. & Ministry of Municipal Affairs (1999) & $\mathbf{x}$ & $\mathbf{x}$ & $\mathbf{x}$ & $\mathbf{x}$ & $\mathbf{x}$ & $\mathbf{x}$ & $\mathbf{x}$ & $\mathbf{x}$ & 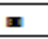 & $\mathbf{x}$ & - \\
\hline 10. & OECD, 1997): & $\mathbf{x}$ & $\mathbf{x}$ & $\mathbf{x}$ & $\mathbf{x}$ & $\mathbf{x}$ & $\mathbf{x}$ & $\mathbf{x}$ & - & $\mathbf{x}$ & $\mathbf{x}$ & $\mathbf{x}$ \\
\hline
\end{tabular}


The steps that should be pursued to promote partnership with private partnership are as follows (M. Jafar Hafsah, Business Partnership, Sinar Harapan, 2000):
i. Building relationships with potential partners
ii. Understand the business conditions of the partner.
iii. Develop strategies and assess business details.
iv. Develop the program.
v. Start the implementation.
vi. Monitor and evaluate progress

Understanding these factors is done by examining 6 (six) stages of the construction project cycle (Proboyo, B., 1998)
i. Identify project activities.
ii. Estimate duration of activity.
iii. Preparation of the project work plan.
iv. Scheduling project activities.
v. Review and analysis of schedules that have been made.
vi. Schedule implementation

Management is the decision-making in a maintenance, when the two terms of management and maintenance in relation to this understanding are slightly different.

The definition of maintenance management is the maintenance organization's activity in an agreed policy. That is, the organization that is considering management and will lead all work activities on maintenance in an agreed contract between the two parties (outsourcing) both the owner of the project, the implementer, and the maintenance management department.

Process Management and Maintenance:
i. Planning
ii. Control
iii. Coordination
iv. Motivate

The main aspects of maintenance

The three main components for the development of maintenance policies in the context of maintenance management, maintenance strategies, and maintenance resources (Seeley, 1987; Spedding, 1989; Barret, 1995; Chanter, 1996; Horner, 1997)

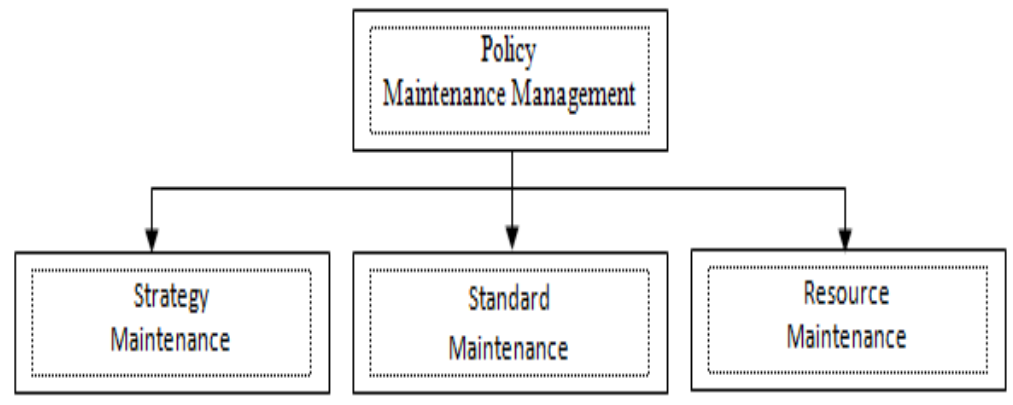

Fig. 5. The main aspects of maintenance

Emphasis in the concept in the construction and development of tourism in Indonesia directed at sustainable development, namely:

i. Tourism destinations; attractions, amenities, accessibility and community empowerment.

ii. Market development and promotion of tourism,

iii. Institutional development (management and regulatory)

iv. Development of space and tourism industry

v. Development of human resources.

vi. Management (environmental, economic, social and cultural )

vii. Development of investment.

viii. Support across sectors. 


\section{SUSTAINABLE DEVELOPMENT}

\section{DISCUSSION}

The definition of sustainable development is most often used is according to the Brundtland Commission in the United States in 1987. This definition is intended to study the past to meet the needs of the present generation without compromising the ability to meet the needs of generations in the future. (Bockisch, 2012; I-LAST V 1:01 2010; VicRoads, 2011; FHWA, 2013).

Sustainable tourism development to meet the needs of present tourists area as host as well as protecting and enhancing opportunities for the future. This is considered as the management of all resources can be met the needs of economic, social and environmental as well while maintaining cultural integrity, (Jamieson \& Noble, 2000).

Sustainable development is an effort to meet the basic needs of all life and develop into an opportunity to meet human aspirations for a better life. The things that support environmentally friendly nature can be described on three pillars, namely economic aspects (known as money or profits). social aspects (known as the human standard requirements) and environmental aspects (known as ecological or earth).

According to Wheeler and Beatley (2004), there are three main pillars that interact with each other, as shown in Figure 3.1 The human need is called sustainable if the standard terms available in a long time. Standard purposes may include air, water, and other original sources. So the environment can provide the basic needs of humans as social beings. Basic human needs' sustainable economy if he has the same chance (equity) to get satisfaction. Although the need for a well-established economic activity can not be separated from their environment, such as air, water, plants, animals for a long time (well worth it).

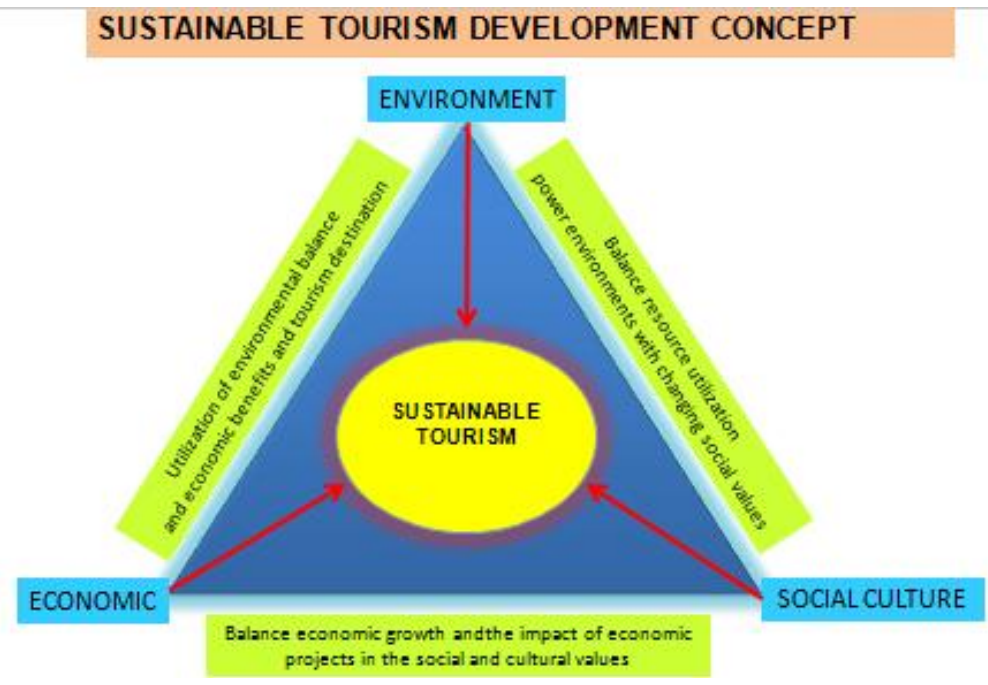

Figure 6. The 3 Pillars Supporting Sustainable development source (Bockish, 2012)

The concept of sustainable development, the use of sustainable development will not be separated from the economic, environmental, social, and cultural. In harmony with this in mind, sustainable development according to Sharpley (2003). encompass all the elements that make up a complete experience. According to scientists Majority (Briguglio, Archer, Jafari, \& Wall, 1996; Butler, 1991; Sharpley, 2000; Vellas \& Becherel, 1999; WCED, 1987) concept of sustainable development related to economic, social and environmental aims at continuous improvement. Rippda and Master Plan (2015), emphasis in the concept in the construction and development of tourism in Indonesia directed at sustainable development, namely:

1. tourism Destinations; attractions, amenities, accessibility and community empowerment.

2. market development and promotion of tourism,

3. Institutional development (management and regulatory)

4. Development of space and tourism industry

5. Development of human resources.

6. Management (environmental, economic, social and cultural

7. Development of investment.

8. Support across sectors. 


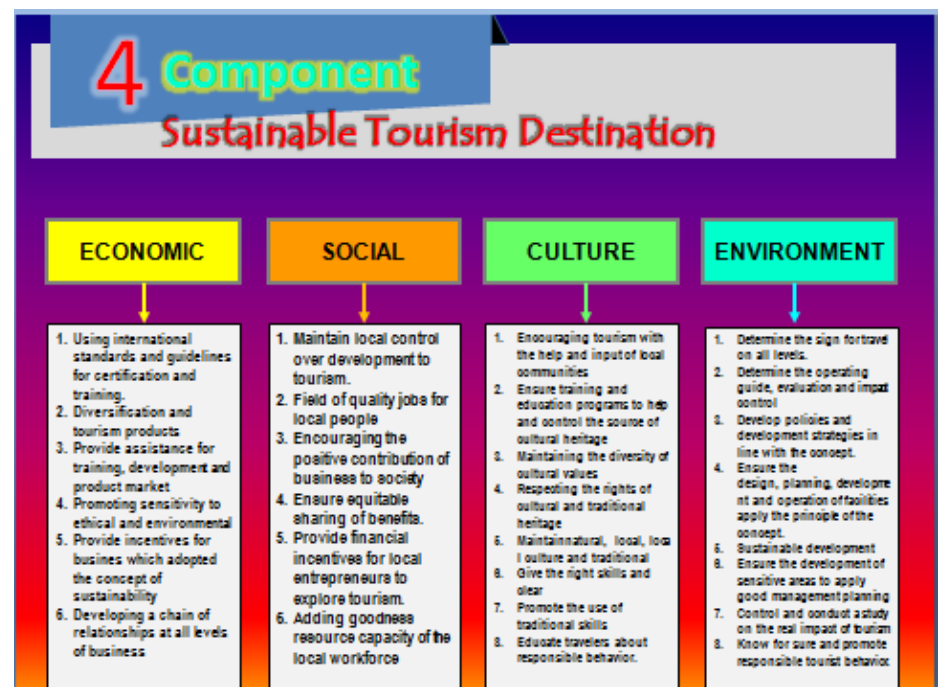

Figure 7. The 4 Component Sustainable Tourism destination

Maintenance is currently considered an integral part of business processes, which is creating added value (Liyanage and Kumar, 2003). Measuring maintenance performance has also become an important requirement for the organization. Maintenance is a combination of every administrative, technical and managerial action undertaken to maintain the item's cycle or return the function to its original or standard / standard form.

\section{CONCLUSION}

The public-private partnership (PPP) partnership has now become a conceptual model in the development of cultural heritage within the local government. There is no agreement from experts that PPP is the answer to the development problems faced by the state and local government. However, they generally agree that PPP is an important approach in designing and implementing development strategies.

In academic level, today there is a trend of change from the conception of government to governance. In the concept of "government", the government is placed as the main actors of development, both at the stage of planning, implementation and evaluation. The government is also the largest funder as well as the largest beneficiary. With the development of a governance paradigm, the pattern of inter-sector (public-private) relationships as well as the relationships between the Center and the regions has become more egalitarian and democratic. In such a pattern, the administration of a particular service or governmental function is no longer dominated by one party ( Government). This means that PPP in the partnership and cooperation process should be more encouraged. It is hoped that through PPP's public-private partnership (PPP), it can create synergy of asset tangible and intangible cultural asset development for the purpose of sustainable tourism destination.

The purpose of PPP development is not only to address the very limited issue of government funds, but also to add value to the maintenance and maintenance project of the public cultural heritage through creativity and innovation of the private sector. The concept of PPP is a complex system involving various stakeholders and institutions. It involves detailed sector knowledge as well as knowledge of financing, risks, and legislation. For Indonesia, the concept of PPP is relatively new, and there is limited experience with regard to the management and maintenance of cultural heritage. Much research is needed to formulate PPP schemes that are appropriate to national social and cultural conditions. PPP regulations are complex, cross-sector, and require harmonization. PPP also requires technical design support and industrial and trade supply chain capacity to enhance the added value of cultural heritage.

The challenges of PPP development in Indonesia are broad and involve regulatory harmonization, enhanced institutional coordination, increased government bureaucracy capacity, improved technical design and capacity of the construction industry, accelerated land acquisition, good governance and fair competition among players. The most important is strong and courageous leadership, and the government's commitment to consistently promote PPP as one of the future culture heritage financing machines.

\section{References}

Abraham, Gena Lester, (2002) Identification of critical success factors for construction organizations in the architectural , engineering, construction $(A / E / C)$ industry 
Proquest Dissertations and Theses (2002) section 0078, Part 0543360 pages; [Ph.D. dissertation].United States Georgia: Georgia Institute of Technology; 2002. Publication Number: AAT 3046868

Allen, G. (2001). The Private Finance Initiative (PFI), London: House of Common Library.

Ashworth, (1991). "Heritage Planning: Conservation as management of change". Geo Press, the Netherlands

Asian Development Bank (ADB), 2008. Public-private partnership handbook. Asian Development Bank

Bloom, N. L. (1996). Selecting the right IS project manager for success. Personnel Management, 75(1), 6-9.

Bockish. J.(2012). Transportation Sustainability Rating Systems. Gresham Smith and Partners. Presentation. http://www.gaite.org/wp-content/uploads/2012/07GAITE-Presentation-Sustainability-July-2012.pdf,[Accessed on 15 February 2013].

Bordignon,M.,Corsi,L.,DeGasperis,D.,Liu,B.,Lukasiewicz,K.,Miccoli,L.,\&Qian,Z. (2009). Sustainable conservation of cultural heritage:Aglobal responsibility. Sichuantowers casestudy.Transition Studies Review,16,379-387.

Bowman,K.S.(2011).ArticleSustainabletourismcertificationandstatecapacity:Keepitlocal, simple, andfuzzy.InternationalJournalofC ulture,TourismandHospitalityResearch,5,269-281.

Bramwell,B.,\&Lane,B.(1999). Article Sustainable tourism: Contributing to the debates. Journal of SustainableTourism,7(1),15.

Bramwell,B.,\&Lane,B.(1993).ArticleSustainabletourism:Anevolvingglobalapproach.Journal of SustainableTourism,1(1),1-5

Buckley,R.(2012). Sustainable tourism: Research and reality. Annals of Tourism Research,39, 528 - 546.

Council of Europe (2006), Heritage for the Future-realising the Economic And Social Potential of a Key Asset-local And Regional, Publication Date: ISBN 10: 9287158622,ISBN 13: 9789287158628

EcologicalTourisminEuropeUNESCO-BRESCE(2009):CriteriaforSustainableTourism.-Publishedwiththe GEF,UNESCO-BRESCEANdMAB.

supportofUNEP-

Horobin,H.,\&Long,J .(1996). Article Sustainable tourism: The role of the small firm. International Journal of Contemporary Hospitality Management,8,15-19.

Hoyer,K.J.(2000).Sustainable tourism or sustainable mobility, The Norwegian case Journal of Sustainable Tourism,8,147-160

Hwang, H.G., Ku, C. Y., Yen, D.V., \& Cheng, C.C. 2004). Critical factors influencing the adoption of data warehouse technology: Astudy of the banking industry in Taiwan. Decision Support Systems

Irandu, E. V. (2006). Sustainable tourism development on Kenya's Coast: A hospitality sector view. Sustainable Tourism Development on Kenya's Coast: A Hospitality Sector View, 17, 189-209

Irandu, E. V. (2006). Sustainable tourism development on Kenya's Coast: A hospitality sector view. Sustainable Tourism Development on Kenya's Coast: A Hospitality Sector View, 17, 189-209.

Jim,C.Y.(2000). Environmental changes associated with mass urban tourism and nature tourism development in Hong Kong. The Environmentalist, 20,233-247.

Joppe,M.(2003).Article Optimizing tourism destination development in Canada. International Journal of Contemporary Hospitality Management, 15,308-311

Jugdev, K \& Müller, R. (2005). Article A retrospective look a tour evolving understanding of project success .Project Management Journal, 36(4), 19-3124

Kaplan,M.,\&Çelik,T.(2008). Article The impact of tourism on economic performance Turkey. The International Journal of Applied Economics \& Finance,2,13-18

KennettHensel,P.A.,Sneath,J.Z.,\&Hensel,P.J.(2010).ArticleDevelopingsustainabletourism:Managers'assessment of Jamaica's ten-year master plan .International Journal of Culture, Tourism and Hospitality Research,4,143-155.

Kernel,P.(2005).Article Creating and implementing a model for sustainable development in tourism enterprises. JournalofCleanerProduction, 13,151-164.

Lee, Sungyoul. (1990) Effective management of information systems in small business organizations: An empirical study of critical success factors Proquest Dissertations And Theses 1990. Section 0138, Part 0454 200 pages; [Ph.D. dissertation].United States -- Nebraska: The University of Nebraska - Lincoln; 1990. Publication Number: AAT 9034280

Lu, X.-H., Huang, L.-H. \&Heng, M. S. (2006). Article Critical success factors of inter-organizational information systems: a case study of Cisco and Xiao Tong in China .Information and Management, 43(3), 395-408

M. M and Thomas J (2006) Article Exploring the role of formal bodies in defining a profession The case of project management, International Journal of Project Management Vol 24 pp 710-721 Management, Architectural Press, Oxford

Magal, S. R., Carr, H. H. \& Watson, H. J. (1988). Critical success factors for information center managers. MIS Quarterly, 12(3), 413-425.

Meredith, J. R. and Mantel, S. (2006), Project management: A managerial approach, 6th,.

Nah, Fiona Fui; Islam, Zahidul; Tan, Mathew. (2007) Article Empirical Assessment of Factors Influencing Success of Enterprise Resource Planning Implementations. Journal of Database Management 18.4 (Oct-Dec 2007), page. 26-50.

Patra, R.2009: Towards Sustainable Development. Sustainable Development. 17:244-256

Pyle, et. al., (1986), An Empirical Examination Of Critical Success Factors For User Based Implementation Projects In Management Information SystemsProquest Dissertations And Theses 1986. Section 0138, Part 0454254 pages; [Ph.D. dissertation].United States -- Nebraska: The University of Nebraska - Lincoln; 1986. Publication Number: AAT 8629538. 
Quental,N.J.M.LourençoandF.N.D.Silva.2011.Sustainable Development Policy: Goals, Targets and Political Cycles. Sustainable Development.19: 15-29.

Reed, R., A. Bilos, S. Wilkinson, and K. W. Schulte. (2009).ArticleInternational Comparison of Sustainable Rating Tools.Journal ofSustainableRealEstate.1(1).

RIPDA (2015), Rencana Induk Pariwisata Daerah Indonesia

Robert,K.H.(2000).Article Tools and Concepts for Sustainable Development, How Do They Relate to a General Framework For SustainableDevelopment, andtoEachOther?JournalofCleanerProduction.8:243-254

Ryghaug, M. (2011). Obstacles to Sustainable Development: the Destabilization of Climate Change Knowledge. SustainableDevelopment.19:157-166.

Seiler, S., Lent, B., Pinkowska, M. \&Pinazza, M. (2012). Article An integrated model of factors influencing project managers' motivation: findings from a Swiss survey. International Journal of Project Management, 30(1), 60-72

Sharpley, R. (2003). Rural tourism and sustainability A Critique. In D.Hall, L. Roberts,\& M. Mitchell (Eds.), New directions in rural tourism (pp. 38-53). Aldershot: Ashgate Publishing Limited.

Sveiby,K.E. (2009).AboriginalPrinciplesforSustainableDevelopment AsTold in Traditional Law Stories. Sustainable Development. 17:341-356.

Williams, Denise. (2004) A Delphi study of critical success factors for launching high-volume, high-traffic Web sites .Proquest Dissertations And Theses 2004. Section 0131, Part 0310154 pages; [Ph.D. dissertation].United States -- Mississippi: The University of Mississippi; 2004. Publication Number: AAT 3159509.

World wide Tourism Organization [WTO].(2003).Retrieved from www.world-tourism.org

WTO.(2001).The concept of sustainable tourism. Retrieved fromhttp://www.worldtourism.org/sustainable/concepts.htm

Yaprak,A.(2008).Culture study in international marketing: Article review and suggestions for future research. International Marketing Review,25,215-229.

Zang, Z., et, al., (2005),Article "A framework of ERP systems implementation success in China: An empirical study" ,International Journal Production Economics 98 pp. 56-80.

Zhang,H.,et, al., (2011). Article The evaluation of tourism destination competitivenesss by TOPSIS \& information entropy A casein the Yangtze River Delta of China. Tourism Management,32,443-451.

Zhao,M., et, al,. (2011).Article Promoting living space protection while ensuring sustainable tourism in Yuhu Village, Lijiang City. International Journal of Sustainable Development World Ecology,18,553-558. 